\title{
The Role of New Media in Travel and Tourism Industry in Morocco: Customers' Attitudes
}

\section{Pr. Hanae AIT HATTANI}

National School of Commerce and Management (ENCG- Fes), Morocco

E-mail: aithanae@gmail.com

\section{Khawla KHOUMSSI}

Sidi Mohamed Benabdelah University, Morocco

\begin{abstract}
The overwhelming emergence of new media, Web 2.0, and cyberspace have dramatically altered the travel and tourism business and have increasingly taken on an essential role in this industry. The growth of new and digital media has created new opportunities for business leaders and service providers to expand and enhance their marketing activities by using different online platforms to reach out to their target consumers. According to the World Travel and Tourism Council (WTTC), the embrace and enhancement of digital marketing are at the heart of this industry's development. Customers are actively using online content to look for information and share experiences, which have strongly influenced and transformed the travel decision-making process. Therefore, this study comes as an attempt to explore the relationship between new media and the travel and tourism industry, focusing on Moroccan media users' practices, attitudes, and opinions. For this purpose, surveys were conducted with a sample of 78 Moroccans aged between 20 and 60 years old. The survey findings confirmed that online communities are increasingly encouraging Moroccan consumers' engagement in the travel and tourism sector, which plays a significant role in business promotion.
\end{abstract}

Keywords: New media; Online communities; Technology; Digital marketing; Travel and tourism business. 


\section{Introduction}

The new media, digital technology, and cyberspace have drastically transformed the ways individuals interact with each other and the ways they perceive different aspects of their lives, especially their choices and decisions. The emerging information and communication technologies (ICTs) and online communities have paved the way to a new era of social, political, and economic contribution and interaction. Daily, people create, share, and exchange different content in social networking sites, blogs, consumer review sites, content community sites, wikis, forums, among other platforms.

Tourism is one of the industries which have been significantly influenced by the new media revolution (Ramos, De Almeida \& Fernandes, 2019). Online communities are increasingly creating new opportunities to engage users in the travel and tourism industry, especially in information search and decision-making behaviors. Moreover, new media is offering tourism service providers (companies and agencies) new strategies of marketing and communication to create more accessible and better services and higher levels of relations. The literature confirms that digital technologies with Web 2.0 are giving birth to a new generation of consumers who are more interactive, adaptive, and flexible (Edelman, 2010; Minazzi, 2015). The new media facilitates social interaction and collaboration between travelers to share experiences with fellow travelers, express opinions, and give recommendations. Besides, it allows service providers to focus on best practices through the feedback they receive from consumers, which subsequently enhances their productivity and revenues.

Taking these trends into consideration, it is of utmost importance to assess the relationship between new media use and the travel and tourism industry in Morocco, emphasizing Moroccan users' practices, preferences, and attitudes. This research relies on a quantitative research method; surveys were conducted with 78 Moroccans aged between 20 and 60 years old to answer the following research questions:

Q1. To what extent are Moroccans engaged in online platforms to plan for and organize their tourist destinations?

Q2. What are the different opinions and attitudes of Moroccans towards the use of new media in the travel and tourism industry?

Q3. What is the impact of new media on consumers' decision making?-

\section{Literature Review}

\subsection{Tourism Industry in Morocco}

Today, tourism in Morocco, as well as in many developing countries, is one of the fastest-growing industries and an essential contributor to the economic development of the country (UNWTO, 2014). The tourism industry is increasingly contributing to Moroccan GDP (direct contribution: 8.6\% of GDP in 2013) and 
employment (direct jobs: 7.6\% of total work in 2013) (WTTC, 2014). Thus, it is considered one of the most vital sectors in Morocco. The Moroccan government has noticed the fundamental role of tourism in the national economic growth and is eager to work more on its promotion at the international level (UNWTO, 2014; Royaume du Maroc, 2014).

\subsubsection{Vision 2010}

Considering the importance of the tourism industry in the economic growth of Morocco in 2001, the government and the General Confederation of Moroccan Enterprises (CGEM) established a new strategy represented through the '2010 vision'. It aims to promote tourism in the country and to allow the Moroccan tourism industry to compete effectively with other tourism sectors in the Mediterranean region, in particular with Tunisia, Egypt, and Turkey (Bouzahzah, \& El Menyari, 2013). Through the "2010 vision," Morocco had for goals to attract ten million tourists by 2010 compared to 4.4 million in 2001 (Water, 2002). The Vision 2010 also aimed at empowering the business to become an influential economic contributor representing 20\% of the national GDP by 2010 (Ministry of Tourism of Morocco).

As a consequence, Morocco has witnessed a significant proliferation in the number of tourist arrivals, which has largely exceeded the number of tourists' arrivals in the last decade, increasing from 4, 333, 900 in 1999 to 9, 213, 700 in 2010 (Observatoire du Tourisme, 2010). At the international level, Moroccan tourism has occupied the 25th place worldwide at the end of 2010 (Roudies, 2010).

\subsubsection{Vision 2020}

As a continuation of the 2010 vision, the Moroccan government keeps on prioritizing the tourism sector and has undertaken a strategic step to collaborate with the private partners to create a new national strategy for the tourism industry represented by the 2020 vision (UNWTO, 2011). The new national tourism strategy has for objectives to make Morocco one of the world's top twenty tourist destinations and a model for sustainable tourism in the Mediterranean area (Roudies, 2010). It also aims to double tourist arrivals and increase tourism receipts to about 140 billion in 2020 against 56 billion dirhams in 2010, and to triple domestic trips (Roudies, 2010). Furthermore, UNWTO (2011) forecasts that by 2020, the number of tourist arrivals in the African area will reach 77 million tourists (Roudies, 2010).

\subsection{The Development of Tourism: \\ Before and After New Media and Web 2.0}

The concept of tourism has evolved from a luxurious experience reserved to very few people (the élites and royalty) into something enjoyed by all the population. At the historical origins of tourism, the ability to travel for leisure was reserved only for royal families and the elites. From the ancient Roman era until the 17th century, 
young men belonging to the upper class were encouraged to travel through Europe on an organized trip known as "grand tour" (Chaney, 2000).

In 1758, the first travel agency was founded by Cox \& Kings (2014). Nearly 100 years later, in 1841, Thomas Cook (2014) started up the first touristic agency, intended to help British people improve their lives by opening up to the world and taking part in the modern life. The unceasing popularity of rail travel and the invention of the automobile technology presented additional milestones in the development of tourism (Auer, 2006, cited in Dhauman \& Chauhan, 2019).

The decade that followed is considered to have been a significant period in tourism development. More travel agencies and companies came to the surface, competing over attracting more customers and highly satisfying their needs, as well as moving toward "mass tourism, introducing new destinations and modes of holidaying” (Gyr, 2010, 32).

At the same time, the increasing use of the Internet has revolutionized the tourism industry. Towards the 2000s, online travel bookings have known a massive growth, and by 2014 the global touristic leader Expedia had expanded to include other brands such as Hotels.com, Trivago, the Hotwire Group, and Expedia Cruise Ship Centers, with earning revenues of over $\$ 4.7$ million (Expedia Inc., 2013).

During the last years, we are witnessing a proliferating use of web tools enabling for users to be at the same time creators, distributors, and consumers of content (multimedia information). The Internet has revolutionized tourism both as a source of information and as a sales channel. The tourism system is now relying more on traveler's reviews, photographs, videos, stories, recommendations, and online marketing. All these components are bringing destinations closer to the potential visitors regardless of how far they are from those destinations. When a tourist is trying to make the final decision upon destination choice, the most critical information comes from online feedback, real-time photographs, and videos as well as recommendations of other travelers, which is called the online word of mouth or (eWOM) (Zivkovic et al., 2014). As a matter of fact, the use of technology enhances usability, provides useful tools and increases bookings, which has primarily helped in decreasing costs and improving travel services to customers within the tourism sector (Standing \& Vasudavan, 2001).

\subsection{The Use of Mobile Phone Technology by Travellers}

The adoption of mobile technologies is another factor that has changed tourists' experiences and behavior. The easy access to information virtually at any time and from anywhere has facilitated travelers' choice of their destinations. The growth of smartphones brings with it also the growth of mobile services payments via mobile phones and mobile apps, especially those designed for tourists, including flight trackers, destination guides, applications customized by online travel agencies, and attraction guides (Romero, 2018). Mobile technologies, especially smartphones, are 
changing the tourist experience and the ways that travel companies interact with their customers (Wang, Park \& Fesenmaier 2012).

It is stated that, nowadays, three out of four travellers have a Smartphone, and they are using them more intensively than ever (Romero, 2018). Travel reservations via mobile phones continue to increase by double numbers every year (Romero, 2018). A recent study by Carlson Wagonlit Travel (CWT) estimated that at the current growth rate in the use of mobile devices, by 2017 , around $25 \%$ of all bookings will be via mobile (Romero, 2018).

\subsection{Social Media Contribution to the Tourism Industry}

Social media plays a significant role both in the supply and demand side of tourism. It allows service providers to have direct interaction with visitors via various Internet platforms, a thing that was unavailable in the past, as they can also monitor and react upon visitors' opinions and evaluations of services. On the other hand, the new social media platforms help travelers to share their personal experiences and views about a destination and also facilitated their interaction with other travelers in case they want to ask for some information during their trip (Romero, 2018). These platforms also allow other travelers to know what other people are doing and what are the attractions and must-see sites in a particular destination (Romero, 2018).

Thanks to Web 2.0 technology features, customers become a source of information and appeal to other potential customers and can increasingly influence them with their own experiences and opinions (Fotis, Buhalis, \& Rossides, 2012). Thus, social media can be considered as one of the useful tools of Web 2.0 in the sector of tourism, through which travel services providers become able to measure the tourists' attitudes, and this is reflected in the increased purchases and recommendations to other users (Zeithaml et al., 2006). A study on the impact of social media on tourism reveals that social media has a significant influence on travel decisions. 44 $\%$ of respondents strongly agreed that Internet posts and opinions helped them to make the initial decision of vacation destinations. $37 \%$ stated that they use online travel forums (i.e., Tripadvisor), 27\% use Facebook, 24\% use Youtube, and $22 \%$ use Pinterest (Királová \& Pavlíčeka, 2015).

Since the emergence of Web 2.0 technology, tourists have been extraordinarily active in the tourism sphere, which strongly impacted the information search, the traveler's decision-making behaviors, and tourism promotion (Standing et al., 2014). Many surveys' findings confirm that approximately $50 \%$ of people around the world tend to download travel apps while searching for destinations before they leave for vacation (Živković et al., 2014).

As a result of the implementation of Web 2.0 technology in the tourism and travel industry, another innovation has seen the light, which is called Travel 2.0; it represents the new generation of travel websites (Del Chiappa, 2011). Its new 
technologies enable travelers to create, share, collaborate, and communicate with other travelers from different areas in the world (Del Chiappa, 2011). The credibility and trustworthiness of Travel 2.0 applications are proliferating, and today`s tourists trust these travel applications more than official tourism organizations (Fotis, Buhalis, \& Rossides, 2012).

\subsection{Digital Marketing in Tourism Business}

The increasing development of ICT, particularly the Internet and the World Wide Web, has created new challenges and opportunities for the tourism sector (Werthner \& Klien, 1999). The importance of the WWW in tourism has grown substantially in recent years, which has radically changed the traditional methods of looking for information (Law, 2000). According to a report by the World Tourism Organization Business Council (2001), nearly 70\% of Internet-using travelers claimed that they used travel agents and called or visited state tourism offices less often. Also, about $70 \%$ of travelers browsing the net reported that they placed fewer calls directly to airline companies.

Access to the Internet as a useful marketing tool is crucial both for tourism businesses and customers. On the one hand, the power of websites which can be manifested in advertising, providing information, exhibiting services, promoting special offers and making them look more appealing, making sales, and providing instant booking and confirmation service to customers without obliging customers to visit any tourism offices (Rayport Jaworski, 2001). On the other hand, WWW allows tourism businesses to enhance their flexibility, interactivity, efficiency, visibility, and competitiveness. Moreover, the use of technology and new media reduces marketing costs compared to traditional marketing media as it removes intermediaries and creates new marketing networks (Rayport Jaworski, 2001). Fantom (1999) suggested that a useful travel Website should act as a virtual customer service representative, enabling customers to search for relevant and reliable travel information. "A Website is a powerful tool offering unique marketing, advertising, product and service information, and communication opportunities between a business and its customers or potential customers" (Kasavana, Knutson, \& Polonowski, 1997).

\section{Methodological Framework}

As previously mentioned, this study seeks to explore the relationship between new media and tourism industry focusing on Moroccan media users' practices, attitudes, and opinions. In other terms, it is an attempt to examine the impact that new media could have on travel and tourism businesses. Based on the stated objective, the following questions are formulated to guide this research:

Q1. To what extent are Moroccans engaged in online platforms to plan for and organize their tourist destinations? 
Q2. What are the different opinions and attitudes of Moroccans towards the use of new media in the travel and tourism industry?

Q3. What is the impact of new media on consumers' decision making?

The research hypothesis emanating from the above research questions is set up as follows: H1: The use of the different new media platforms by Moroccan consumers is increasingly developing the sector of tourism and industry.

Thus, to answer these question and hypothesis, this paper reports the findings of a survey completed by 78 Moroccan citizens. The survey was internet-based, combining both closed-ended and open-ended questions. The latters were related to respondents' demographics, new media use and practices, and attitudes towards the use of new media in the travel and tourism industry.

Socio-demographic information on gender, age, study level, country of residence, marital, and professional status were collected. As reported in table 1, out of 78 respondents, $45 \%$ were males, and $55 \%$ females. As for the age group, respondents

Table 1. Distribution of percentages and demographics

\begin{tabular}{|c|c|}
\hline Demographics & Percentage \\
\hline $\begin{array}{l}\text { Gender } \\
\text { - Male } \\
\text { - Female }\end{array}$ & $\begin{array}{l}45 \% \\
55 \%\end{array}$ \\
\hline $\begin{array}{l}\text { Age } \\
\begin{array}{l}\text { - Less than } 20 \\
\text { - } 20 \text { to } 29 \\
\text { - } 30 \text { to } 39 \\
\text { - } 40 \text { to } 49 \\
\text { - } 50 \text { to } 59\end{array}\end{array}$ & $\begin{array}{c}10 \% \\
35 \% \\
33 \% \\
13 \% \\
9 \%\end{array}$ \\
\hline $\begin{array}{l}\text { Country of Residence } \\
\text { - Morocco } \\
\text { - Abroad }\end{array}$ & $\begin{array}{c}93 \% \\
7 \%\end{array}$ \\
\hline $\begin{array}{l}\text { Study Level } \\
\text { - Primary School } \\
\text { - Secondary School } \\
\text { - At the University } \\
\text { - License } \\
\text { - Master (School of Business/ Engineering) } \\
\text { - Doctorate }\end{array}$ & $\begin{array}{c}0 \% \\
0 \% \\
14 \% \\
13 \% \\
36 \% \\
37 \%\end{array}$ \\
\hline $\begin{array}{l}\text { Professional Status } \\
\text { - Student } \\
\text { - Employed in the Public Sector } \\
\text { - Employed in the Private Sector } \\
\text { - Self-employed } \\
\text { - Unemployed }\end{array}$ & $\begin{array}{c}29 \% \\
48 \% \\
17 \% \\
6 \% \\
0 \%\end{array}$ \\
\hline $\begin{array}{l}\text { Marital Status } \\
\text { - Single } \\
\text { - Married } \\
\text { - Divorce }\end{array}$ & $\begin{array}{c}50 \% \\
48 \% \\
2 \%\end{array}$ \\
\hline
\end{tabular}


aged 20-29 represented the most dominant category, with a percentage of $35 \%$, followed by those aged between 30 and 39 (33\%). Respondents were all Moroccans, $93 \%$ are living in Morocco, while $7 \%$ are immigrants. For study level, 37\% have a doctorate, $36 \%$ have a master's degree, $13 \%$ have a license, and $14 \%$ are currently studying at the university. Besides, regarding the professional status, $29 \%$ were students, $48 \%$ were employed in the public sector, $17 \%$ in the private sector, and $6 \%$ were self-employed. Finally, respondents were asked to identify their marital status, $50 \%$ were single, $48 \%$ were married, and $2 \%$ were divorced.

\section{Findings}

This section addresses the main objective of this study, which is the exploration of the impact of new media use on Moroccans' tourist participation. In other terms, it examines the extent to which new media can be used to drive tourism. Seventyeight new media users answered a survey aimed at garnering information about their online practices, attitudes, and motivations.

\subsection{Moroccans' Usage of New Media}

The paper examines the sample's frequency of new media use. Figure 1 shows that $36 \%$ of the sample claimed that they are always active in online communities, and $23 \%$ usually busy. Besides, as highlighted in figure 2, the majority of respondents (23\%) confirmed that they actively use Facebook, while $20 \%$ mostly use WhatsApp, and $18 \%$ use Google.

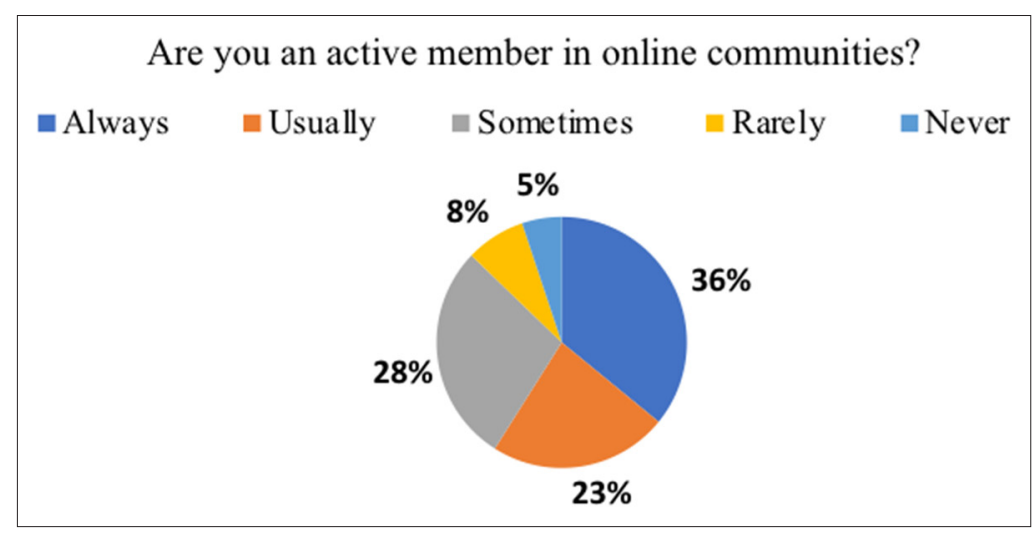

Figure 1. Respondents' Frequency of Online Communities' use 


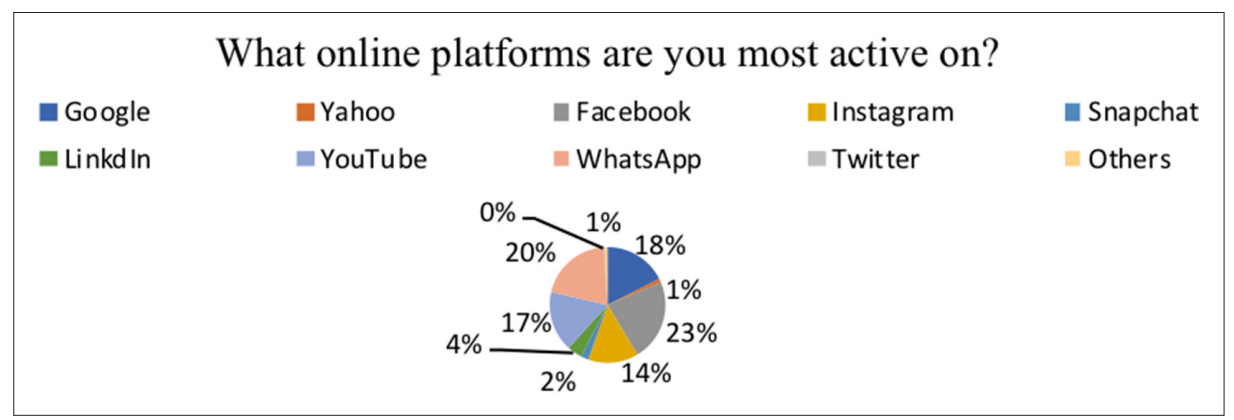

Figure 2. Online Platforms Used by Respondent

After examining the overall frequency of new media use by respondents, the survey highlighted their use of the platforms mentioned above in organizing their tourist stays and visits, such as in searching for information and new destinations, making reservations. Figure 3 demonstrates that $24 \%$ of the sample always uses online communities to plan and organize their trips and visits, $29 \%$ usually do, $31 \%$ sometimes do, and only $10 \%$ who have never used them for the purpose in question.

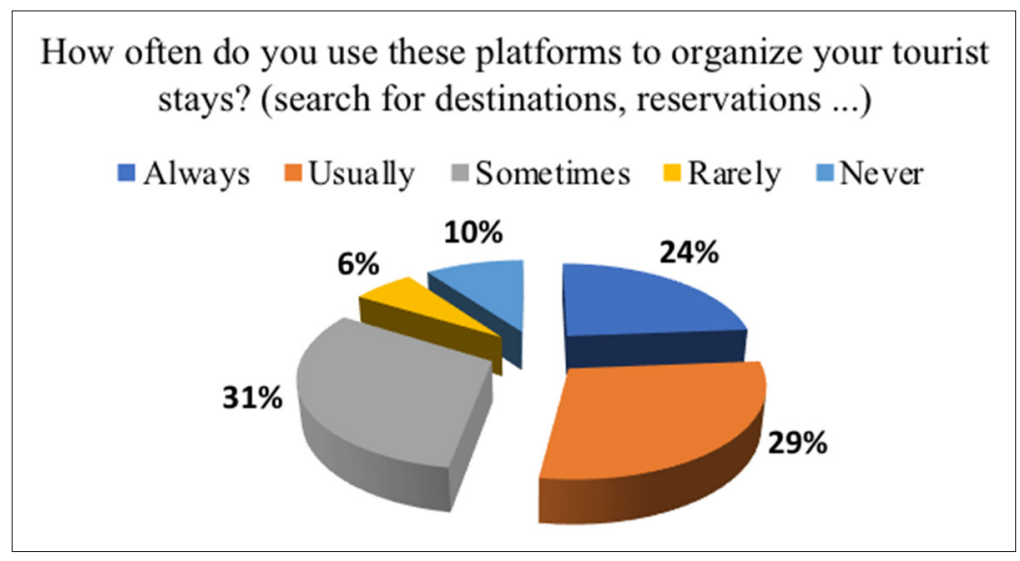

Figure 3. Online Platforms' Frequency of use in organizing tourist stays

\subsection{Patterns of New Media Use \\ in Travel and Tourist Business by Moroccans}

After examining respondents' demographic information and their new media usage, the third section in the survey sheds light on the different patterns of new media use in travel and tourist business by Moroccans. The first question within this section underscores respondents' sources of information and communication used in planning and organizing their trips and visits. As shown in figure 4, search engines (Google, Yahoo) are the most common online source of information used 
by respondents (66\%), followed by social networking sites (60\%), family, friends, and colleagues (55\%), YouTube (25\%), forums and online blogs $(20 \%)$, and other media like TV, print, and radio (7\%). On the other hand, only $17 \%$ stated that they ask for information from travel agencies and $2 \%$ from tour guides.

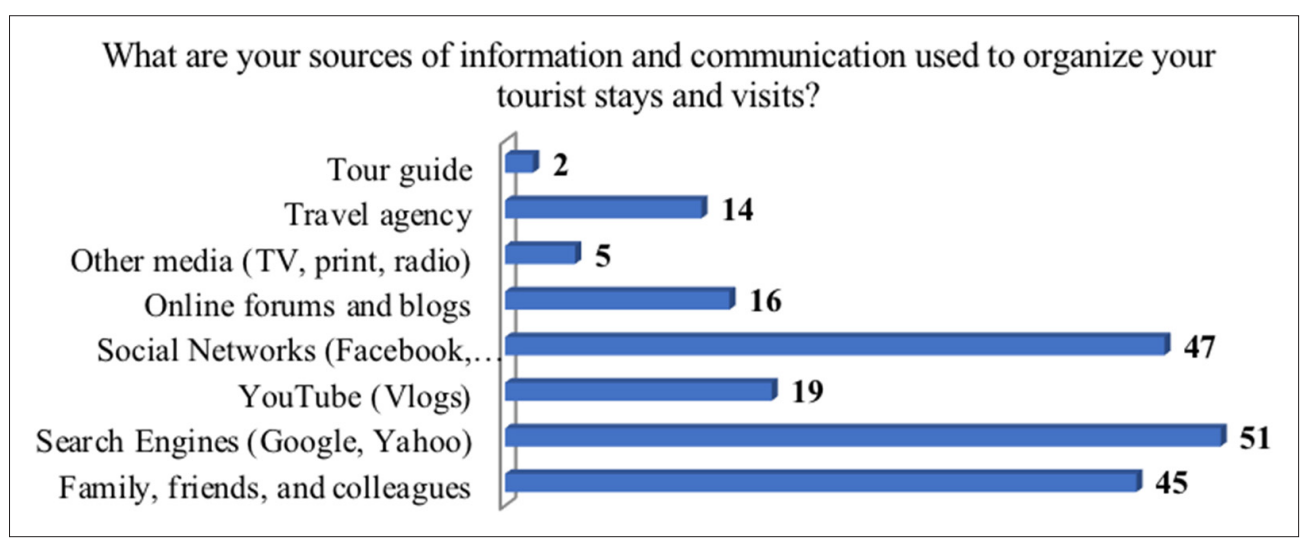

Figure 4. The sources of information and communication used to organize tourist stays and visits (frenquency).

Moreover, the survey sought to examine the different websites that Moroccans access to look for information and organize their tourist stays and trips. As represented in Figure 5, the majority of respondents use Booking (76\%) and Google $(67 \%)$.

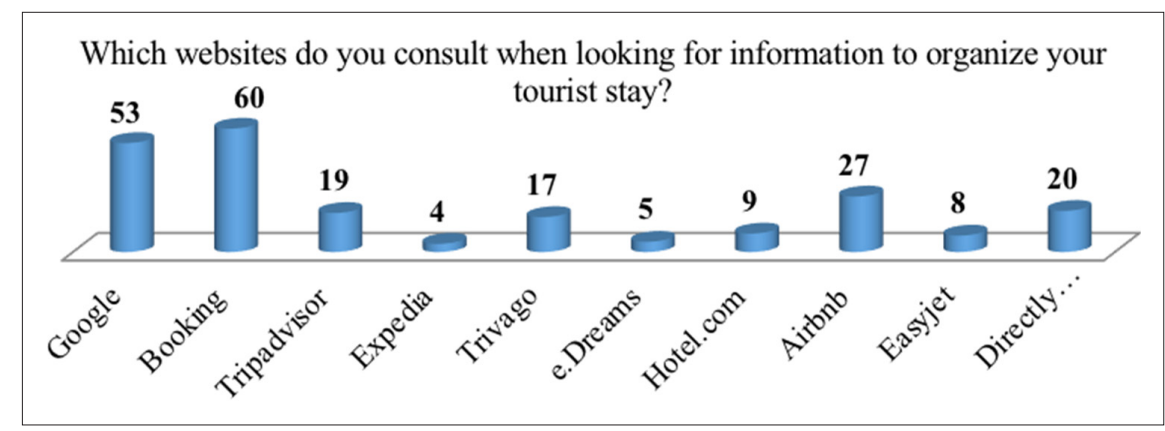

Figure 5. Websites used for information search to organize tourist stays

Subsequently, to investigate the relationship between new media use and tourist business, it was essential to explore for what purposes do Moroccans use the previously mentioned online communities. Figure 6 shows that $89 \%$ use online media platforms to look for information, $54 \%$ to purchase a flight, train or boat tickets, $53 \%$ to book in hotels, $20 \%$ to enter to attraction sites, $16 \%$ to organize an all-inclusive stay, $13 \%$ to rent a car, and $7 \%$ to book in a restaurant. 


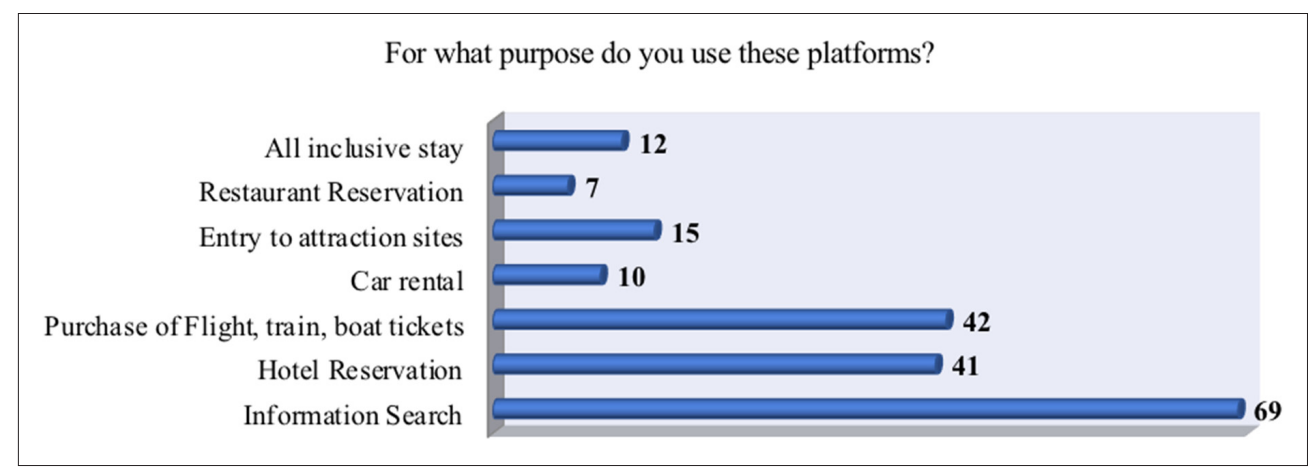

Figure 6. Respondents' purpose(s) for using online platforms

As for their tourist destinations, respondents stated that they use online communities to organize their trips both in Morocco (51\%) and abroad (49\%) (Figure 7).

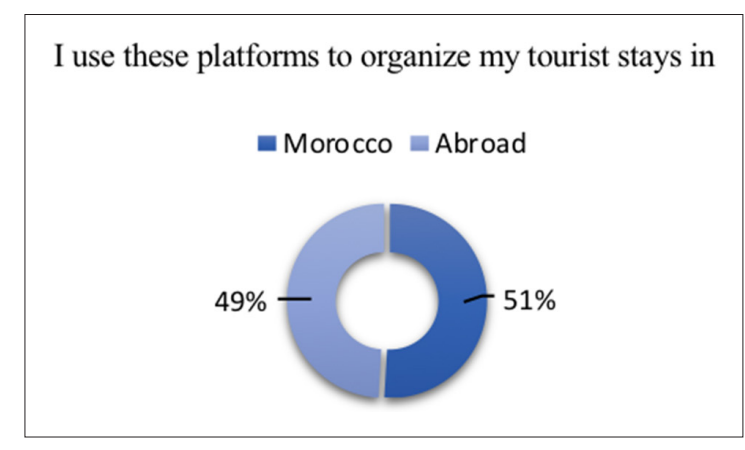

Figure 7. Moroccans' tourist destination(s) using new media

Moreover, the survey focused on understanding the advantages that online platforms offer to Moroccans while looking for information and organizing their tourist stays. Table 2 highlights that $72 \%$ prefer online service. It allows them to compare prices quickly, $62 \%$ said that it gives them easy access to several offers, $55 \%$ confirmed that it facilitates the checking of availability at any time, $54 \%$ stated that online service is more comfortable and timesaving. Also, it offers them a chance to have access to pictures and videos as well as different opinions of other internet users. Additionally, 44\% use an online service to take advantage of discounts and special offers. $21 \%$ found that it is the best way to communicate with tourist service providers, and $19 \%$ said that it is more reliable. 
Table 2. Advantages of Using Online Services in Organizing Tourist Stays and Visits

\begin{tabular}{lc}
\hline \multicolumn{1}{c}{ Advantages } & Percentage \\
\hline Checking availability & $55 \%$ \\
Comparing prices & $72 \%$ \\
Online discounts & $44 \%$ \\
Having easy access to several offers and services & $62 \%$ \\
Speed and ease of service & $54 \%$ \\
Reliability of service & $19 \%$ \\
Possibility of seeing photos and videos as well as knowing & $54 \%$ \\
the different opinions of other Internet users & $21 \%$ \\
\hline The best way to communicate with service providers & \\
\hline
\end{tabular}

On the other hand, Table 3 presents the different shortcomings of online platforms and reasons why Moroccans do not use online platforms to look for information and organize their tourist stays. Fifty percent of the respondents do not use online platforms because they do not trust the online payment service, $31 \%$ because they do not have a credit card, $24 \%$ because they consider the online service non-reliable, $18 \%$ because of the absence of human contact. Lack of information, $16 \%$ because they find that online processes are complicated in use, and finally, $15 \%$ do not consider the online offers attractive.

Table 3. Shortcoming and Reasons why Moroccans do not use online services in organizing tourist stays and visits

\begin{tabular}{lc}
\hline \multicolumn{1}{c}{ Shortcomings } & Percentage \\
\hline No credit card & $31 \%$ \\
Lack of trust and security in online payment & $50 \%$ \\
Online offers are not attractive & $15 \%$ \\
Lack of human contact & $18 \%$ \\
Lack of Information & $18 \%$ \\
Lack of reliability & $24 \%$ \\
The online processes are complicated in use & $16 \%$ \\
\hline
\end{tabular}

3.3 The Impact of New Media on Respondents' tourist Choices and Decisions.

The fourth and last section of the survey considered internet users' different attitudes towards the impact of new media use on their tourist choices and decisions. As shown in Figure 8, 55\% confirmed that they are usually satisfied with the online services in organizing their tourist stays and visits. 


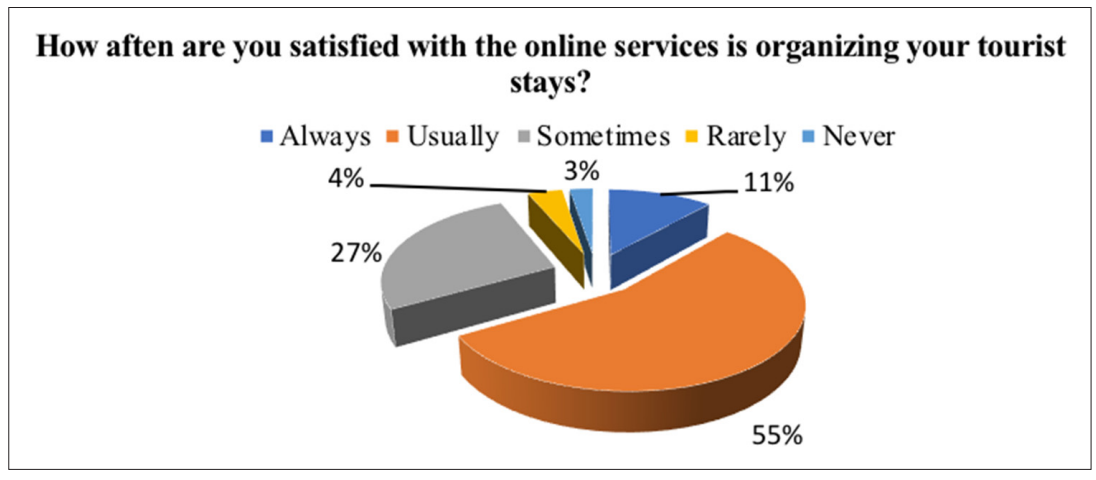

Figure 8. Respondents' level of Satisfaction vis-à-vis Online Services

After examining respondents' level of satisfaction vis-à-vis online services, they were asked about the influence that online content can have on their choices and decisions. That is, the study sought to determine the extent to which new media influence the decision-making processes when the respondents are engaged in travel plans. According to Table 4, the majority of respondents said that online contents have a positive influence on their choice and decision making while organizing their tourist trips. For instance, $43 \%$ usually take online comments, opinions, and recommendations into consideration, and $44 \%$ often get attracted by the pictures and videos shared by other users. On the other hand, 37\% sometimes share their content online to help other users in making their choices and making their decisions while organizing their tourist trips.

Table 4. Influence of online content on users' tourist choices and decisions

\begin{tabular}{lccccc}
\hline & Always & Usually & Sometimes & Rarely & Never \\
\hline $\begin{array}{l}\text { The opinions, comments, and recommendations } \\
\text { of Internet users influence my choice }\end{array}$ & $12 \%$ & $43 \%$ & $38 \%$ & $2 \%$ & $5 \%$ \\
$\begin{array}{l}\text { The pictures and videos shared } \\
\text { by Internet users influence my choice }\end{array}$ & $10 \%$ & $44 \%$ & $41 \%$ & $1 \%$ & $4 \%$ \\
$\begin{array}{l}\text { My decision might be changed } \\
\text { after checking and reviewing the online content }\end{array}$ & $10 \%$ & $25 \%$ & $54 \%$ & $6 \%$ & $5 \%$ \\
$\begin{array}{l}\text { I share my content online to help my community } \\
\text { in their choices and decisions (sharing pictures, } \\
\text { videos, comments, recommendations) }\end{array}$ & $9 \%$ & $22 \%$ & $37 \%$ & $20 \%$ & $12 \%$ \\
\hline
\end{tabular}

Finally, figure 9 exposes respondents' opinions towards the role of new media in developing the tourism industry and business. The majority $(71 \%, \mathrm{~N}=56)$ agrees on the fact that new media promotes the sector of tourism. 


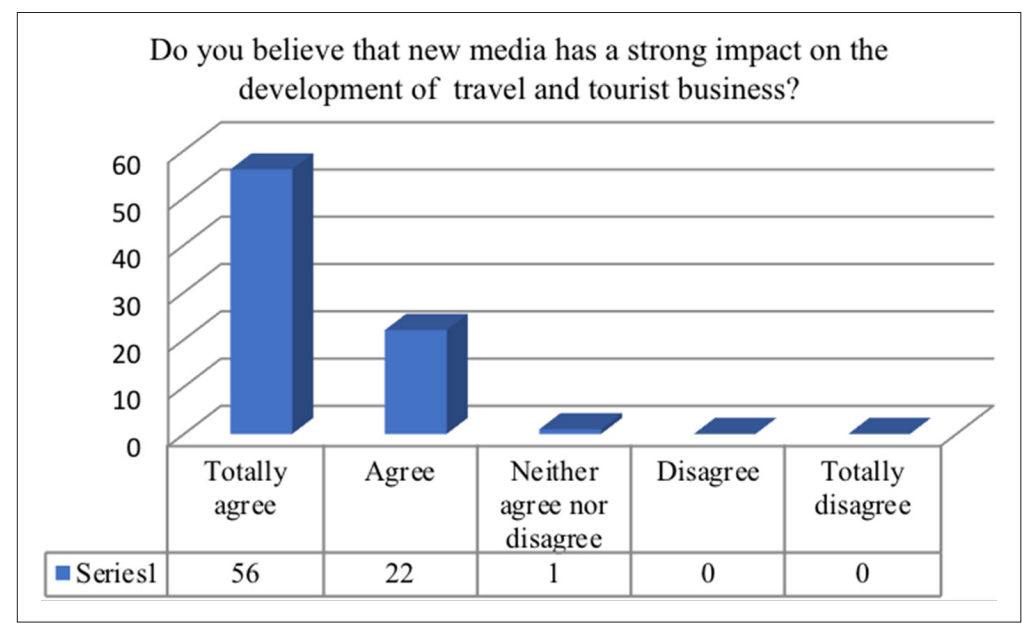

Figure 9. Respondents' Opinion on the Impact of New Media on Travel and Tourism Business Development

\section{Discussion and conclusion}

This chapter discusses the research findings and the emergent themes to understand the lived practices and experiences of Moroccan internet users as well as their different attitudes to explore the impact of new media on the tourism and trip industry.

The quantitative results presented earlier in this paper imply that youth's new media experiences continue extending their interest and engagement in tourism and travel business. Moreover, the majority confirmed that the emergence of new media and technology tools is increasingly participating in the development of this industry, which corroborated the research hypothesis.

The current study sought to examine respondents' regular use of new media. According to survey findings, Moroccan citizens, represented by the sample assigned for this research, are actively using technology, and having access to the online communities, especially Facebook and Google. Based on research established in 2014 on the use of popular social media platforms, Scaife (2014) confirmed that Facebook counted 1.23 billion active users while Twitter recorded 5,700 per second. Respondents stated that in addition to the regular daily use of online media, they use it in organizing their tourist trips by searching for travel-related information, namely destination, accommodation, and transportation.

As Ho and Liu (2005) maintained, the internet era and globalization are playing a crucial role in travel-related information searching, especially using social media and search engines (cited in Wang and Pizam, 2011). These platforms make the process much easier and more efficient. The survey results found that, in addition to information searching, users are actively engaged online in making 
hotel reservations and purchasing flight, train, and boat tickets. In the same line of thought, Kozak and Kozak (2013) said that online services allow customers to perform most hotel searching and purchasing conveniently.

Therefore, it was essential to understand the reasons why online services seem to be increasingly used in the tourist and travel industry. The survey findings highlighted that the majority of respondents use these communities because they can have easy access to several services and offers. Also, they can easily compare prices and check availability. Other respondents said that online platforms facilitated communication with service providers. Hatz (2013) pointed out that online services are considered interesting thanks to five features, namely information representation, collaboration, communication, interactivity, and transaction (cited in Ramos, De Almeida, and Fernandes, 2019). However, the same respondents said that they feel reluctant towards online services because of the lack of trust and reliability. In the same context, Martin (2004) explained that:

The WWW offers an unlimited virtual repository of information and services with unlimited reach. However, access, availability, and reliability of the Internet remain a challenge even in some developed countries such as the UK, implying that this will be a significant handicap for e-business (Information Resources Management Association, 2015, 617).

That is to say, despite perceiving online platforms as accessible service providers and facilitators, customers still hesitate to trust the Internet and feel confident to fulfill their travel arrangements. On the other hand, while exploring the influence of new media on users' decision-making process, the survey findings confirmed the positive relationship that exists between consumers' trust and their decisionmaking. Respondents pointed out that they are increasingly trusting and being influenced by the pictures, videos, and reviews done by other customers and shared on the online communities. Skift.com (Skift, 2014), the largest industry intelligence and marketing platform in the tourism industry, maintain that travel reviews are growingly becoming a more significant and trustworthy factor in the decisionmaking process. Besides, in a similar study, Mikalef, Giannakos \& Pateli (2013) found that social media users are highly influenced by the posts, including reviews, pictures, and videos that other users share on their timelines concerning the tourist products and services they had used. Online communities are drastically altering different aspects of our lives, and dramatically affecting our attitudes and behaviors. Users can be easily influenced by the information shared by fellow consumers about products and services, which increases their needs, interest, and purchasing power.

Similarly, Munar and Jacobsen (2013) further observed that most social media users consider the information posted in forms of reviews on websites such as TripAdvisor to be $100 \%$ sincere, trustworthy, and reliable. Subsequently, this was confirmed by the current research respondents who expressed their satisfaction with their online experiences in planning and organizing their tourist trips. 
According to Truch (2006), the measurement of customer satisfaction is central to the success of any marketing concept (cited in Information Resources Management Association, 2015).

Overall, the travel and tourism industry is one of the largest business sectors that extensively use new media and technology by both customers and service providers. This research, hence, confirms the assumption that new media is increasingly raising Moroccans' interest in the travel business; they use online platforms such as social networks, blogs, and websites to look for information, make reservations, post reviews, and share recommendations. The new media is offering various opportunities for users to increase their needs and interests in tourist services thanks to its features of information presentation, communication, interactivity, collaboration, and transaction.

Like all research projects, this study has some limitations. First of all, the sample size was limited. Despite using the internet-based, the number of respondents did not exceed 78 . The online option was adopted in this study, aiming to attract more participants, but it did not. The sample seems small to be considered for representativeness. It raised the issue about the generalizability of findings.

Furthermore, this research was mainly quantitative. Future studies should also build on qualitative research, such as interviews. Despite these limitations, the overall findings remain grounded in a robust research platform and raise several stimulating guidelines for future orientations. Research on new media in tourism is in its infancy; thus, it is critical to conduct more inquiries to carefully and systematically consider the role of new media in promoting the travel and tourism business and demonstrating its economic contribution to the industry. For instance, future studies are recommended targeting practitioners and service providers to understand the extent to which professionals rely on online communities to expand their services and increase their profit. On the other hand, it is also crucial that future researchers also investigate on the drawbacks of new media use in travel and tourism business such as online theft and fraud, fake surveys, etc. to improve and further extend the decisive role that new media can have in the sector.

\section{References}

1. Bouzahzah, M., \& El Menyari, Y. (2013). International tourism and economic growth: thecase of Morocco and Tunisia. The fournal of North African Studies, 18(4), 592-607.

2. Chaney, E. (2000). The evolution of the grand tour: Anglo-Italian cultural relations since the Renaissance. Portland, OR: Routledge.

3. Cox \& Kings. (2014). Retrieved on March 5, 2020 from https://www.coxandkings.com/ about-us/index.shtml.

4. Del Chiappa, G. (2011). Trustworthiness of travel 2.0 applications and their influence on tourist behavior: an empirical investigation in Italy. In Law, R., Fuchs, M.\& Rucci, F. 
(Eds.), Information and Communication Technologies in Tourism (pp. 331-342). New York: Springer.

5. Dhauman, M.C. \& Chauhan, V, C. (2019). Handbook of Research on International Travel Agency and Tour Operation Management. USA: IGI Global.

6. Edelman, D. (2010). Branding in the digital age. Harvard Business Review, 88(12), 62-69.

7. Expedia, Inc. (2013). Expedia: Annual report, 2013. Retrieved on March 2020, from http:// files.shareholder.com/downloads/EXPE/3546131959x0x750253/48AF365A-F894-4E9C8F4A-8AB11FEE8D2A/EXPE_2013_Annual_Report.PDF.

8. Fantom, L. (1999). Creating a travel website that takes your customers where they want to go. HSMAI Marketing Review, 16(3), 29-31.

9. Fotis, J., Buhalis, D., Rossides, N. (2012) Social media use and impact during the holiday travel planning process. Information and Communication Technologies in Tourism, 13-24.

10. Gyr, Ueli. (2010). The history of tourism: Structures on the path to modernity. European History Online (EHO). Retrieved on January 2020, from http://ieg-ego.eu/en/threads/ europe-on-the-road/the-history-of-tourism.

11. Information Resources Management Association (2015). Hospitality, Travel, and Tourism: Concepts, Methodologies, Tools, and Applications. USA: Business Science Reference.

12. Királová, A., \& Pavlíčeka, A. (2015). Development of Social Media Strategies in Tourism Destination. Procedia - Social and Behavioral Sciences, 175, 358-366. doi: 10.1016/j.sbs pro.2015.01.1211.

13. Kozak, M., \& Kozak, N. (2013). Aspects of Tourist Behavior. Cambridge: Cambridge Scholars Publishing.

14. Law, R. (2000). Internet in Travel and Tourism- Part I. Journal of Travel \& Tourism Marketing, 9(3), 65-71.

15. Mikalef, P., Giannakos, M., \& Pateli, A. (2013). Shopping and word-of-mouth intentions on social media. Journal of Theoretical and Applied Electronic Commerce Research, 8(1), 17-34.

16. Minazzi, R. (2015). Social Media Marketing in Tourism and Hospitality. Switzerland: Springer.

17. Munar, A. M., \& Jacobsen, J. K. S. (2013). Trust and involvement in tourism social media and web-based travel information sources. Scandinavian fournal of Hospitality and Tourism, 13(1), 1-19.

18. Observatoire du Tourisme au Maroc (2010). Retrieved on January 2020, from. https:// www.tourisme.gov.ma/sites/default/files/tbnat-12-17-.pdf.

19. Ramos, C.M., De Almeida, C. R., \& Fernandes, P. O. (2019). Handbook of Research on Social Media Applications for the Tourism and Hospitality Sector. Business Science Reference.

20. Rayport, F. J \& Jaworski, B. J. (2001). E-commerce. Boston: McGraw-Hill/Irwin.

21. Roudies, N. (2013). Vision 2020 for tourism in Morocco: focus on sustainability and ecotourism. Expert Group Meeting on Ecotourism, Poverty Reduction \& Environmental Protection. Retrieved on Deecember 2019 from https://sustainabledevelopment.un.org/ content/documents/4104roudies.pdf. 
22. Scaife, L. (2014). Handbook of social media and the law. New York: Informa Law from Routledge.

23. Skift (2014). "Facebook More Popular than Review Sites for Trip Sharing." Retrieved on January 2020, from https://skift.com/2014/07/25/facebook-more-popular-than-reviewsites-for-trip-sharing/.

24. Standing, C., \& Vasudavan, T. (2001). The Impact of Electronic Commerce on the Travel Agency Sector, fournal of Information Technology Case and Application Research, 3(1).

25. Standing, C., Tang-Taye, J.P., \& Boyer, M. (2014). The Impact of the Internet in Travel and Tourism: A Research Review 2001-2010. Journal of Travel \& Tourism Marketing, 31(1), 82-113.

26. The World Tourism Organization Business Council. (2001). E-business for tourism: practical guidelines for tourism destinations and businesses. Retrieved on January 2020, from https://www.worldcat.org/title/e-business-for-tourism-practical-guidelines-for-to urism-destinations-and-businesses/oclc/48947212.

27. UNWTO Tourism Highlights. (2011). Retrieved on January 2020, from https://www. eunwto.org/doi/pdf/10.18111/9789284415366.

28. UNWTO Tourism Highlights. (2014). Retrieved on January 2020, from https://www. eunwto.org/doi/pdf/10.18111/9789284416226.

29. Wang, D., Park, S., \& Fesenmaier, D. R. (2011). The Role of Smartphones in Mediating the Touristic Experience, fournal of Travel Research, 51(4), 371-387.

30. Wang, Y, \& Pizam, A. (2011). Tourism Destination Marketing and Management: Collaborative Strategies. Cambridge: CAB International.

31. Werthner, H \& Klien, S. (1999). Information, technology and tourism: A challenging relationship. Austria: Springer Computer Science.

32. Zeithaml, V., Bitner, M.J. \& Gremler, D. (2006). Services Marketing: Integrating Customer Focus Across the Firm. New York: McGraw Hill. 